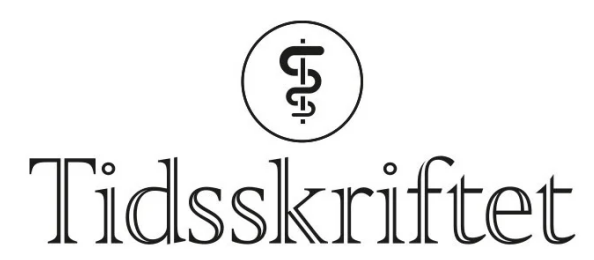

DEN NORSKE LEGEFORENING

\title{
Hanskerelatert håndurtikaria
}

\author{
KORT KASUISTIKK
}

\section{HILDE HEIRO}

hiheir@ous-hf.no

Seksjon for miljø- og arbeidsmedisin

Oslo universitetssykehus

Hilde Heiro er lege i spesialisering i arbeidsmedisin.

Forfatteren har fylt ut ICMJE-skjemaet og oppgir ingen interessekonflikter.

\section{INGVILL SANDVEN}

Seksjon for miljø- og arbeidsmedisin

Oslo universitetssykehus

Ingvill Sandven er spesialist i arbeidsmedisin og overlege.

Forfatteren har fylt ut ICMJE-skjemaet og oppgir ingen interessekonflikter.

\section{TERESA LøVOLD BERENTS}

Regionalt senter for astma, allergi og overfølsomhet (RAAO) og Seksjon for hudsykdommer Oslo universitetssykehus

Teresa Løvold Berents er ph.d., spesialist i hud og veneriske sykdommer, godkjent i kompetanseområdet allergologi, og overlege.

Forfatteren har fylt ut ICMJE-skjemaet og oppgir ingen interessekonflikter.

\section{En sykepleier med hudplager relatert til hanskebruk på arbeid hadde tidligere blitt utredet for kontaktallergi, med negative funn. Man mistenkte etter ny utredning en sykdom som sannsynligvis er underdiagnostisert og en viktig differensialdiagnose til kontaktallergi.}

En kvinnelig nyutdannet sykepleier i 2o-årene var henvist til arbeidsmedisinsk poliklinikk for vurdering av hudplager som debuterte forholdsvis raskt etter at hun begynte å bruke engangshansker regelmessig i praksis og i arbeid som sykepleierstudent. Hun beskrev svie og rødme på håndrygger kort tid etter å ha tatt av seg engangshansker. Hudplagene forsvant spontant i løpet av få minutter. Plagene kom etter bruk av alle typer hansker i arbeid og uavhengig av hvor lenge hun hadde hatt hanskene på. Hun hadde hatt atopisk eksem som barn, men hadde ingen kjent allergi.

Hun var som sykepleierstudent utredet hos hudlege med standard epikutantest. Denne utelukket allergi mot gummitilsetningsstoffer i engangshansker. Spesifikt IgE for lateks var negativ. Det ble forsøkt kortvarig behandling som ved kronisk urtikaria (elveblest) med 
høydose annengenerasjons antihistamin, desloratadin, en tablett fire ganger daglig, uten effekt.

Hun ble nå utredet videre med prikktest på hanskemateriale og lateks. Disse var negative.

Dermografismetest med trespatel på ryggen ga umiddelbart rødhet, som var til stede etter 20 minutter. Pasienten opplevde ingen plager ved denne testen. Testing med bruk av forskjellige hansketyper viste ingen subjektive plager da hun hadde hanskene på, men erytem på håndryggen når hun tok hanskene av (figur 1). Pasienten beskrev svie på områdene med erytem. Ved testing med trang og rommelig hanske var plagene mildere og forsvant raskere ved bruk av den rommelige hansken (se video).
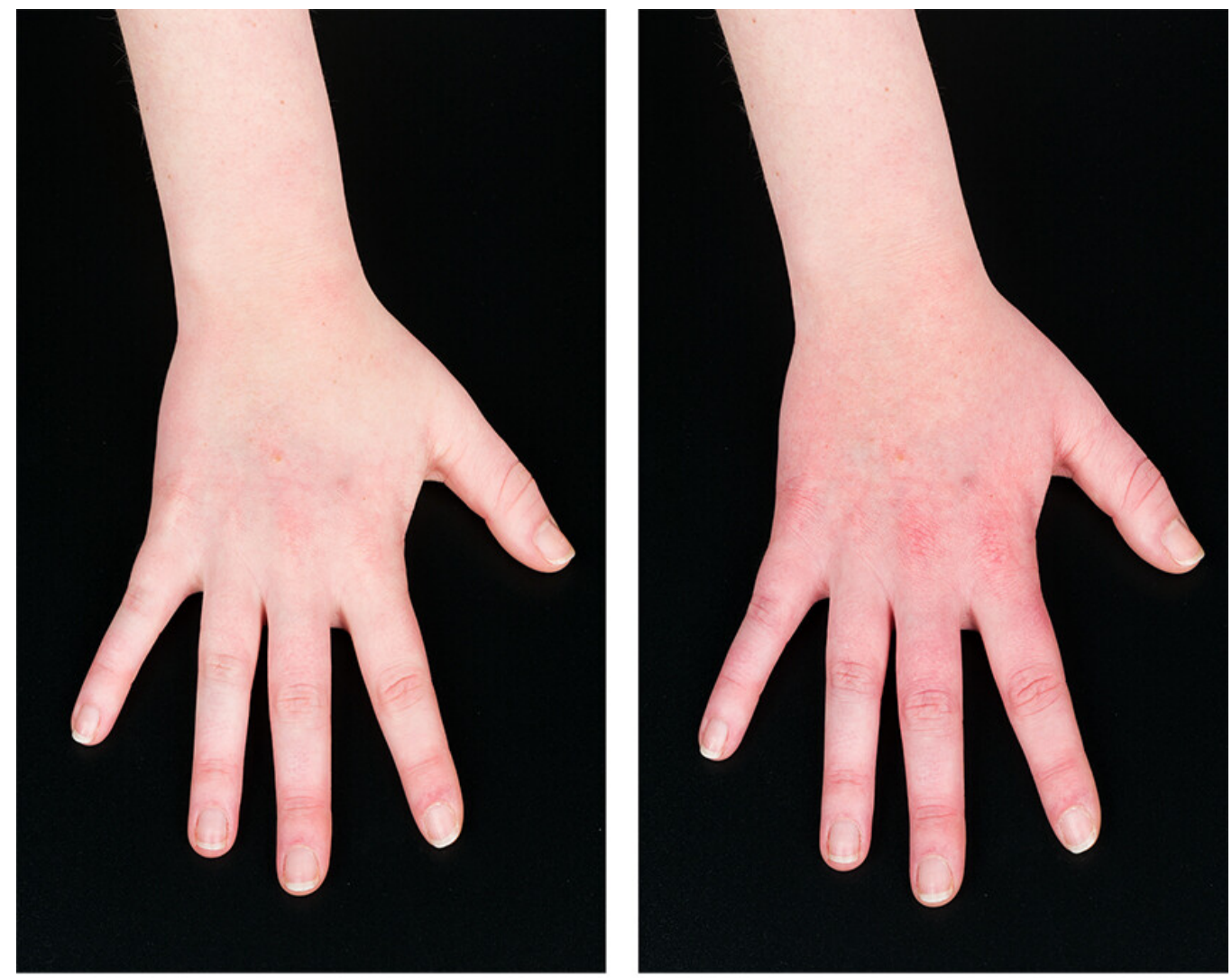

a

b

Figur 1 Pasientens hånd før (a) og etter bruk av hanske (b). Urtikariell hudreaksjon oppsto kort tid etter at hansken ble tatt av.

Det ble mistenkt hanskerelatert håndurtikaria (1),(2). Pasienten prøvde igjen ut behandling med høydose annengenerasjons antihistamin (cetirizin), to tabletter to ganger daglig. Hun hadde tørr hud på hendene og ble derfor anbefalt intensivert barrierebehandling med en fuktgivende krem med høyt fettinnhold (70\%) og en krem med fuktgivende komponent (karbamid). 
Pasienten opplevde ingen bedring av plagene ved bruk av antihistaminer, men rapporterte at jevnlig smøring med kremer hadde noe effekt. Ettersom det er en teoretisk mulighet for at residiverende urtikaria kan føre til kronisk eksem, ble hun anbefalt å forsøke å unngå å utløse utbrudd av urtikaria ved å bruke rommelige hansker i arbeid. Hun har fått sykdommen godkjent som yrkessykdom. Pasienten har nå arbeid med begrenset hanskebruk, og man anser at sykdommen vil kunne begrense hennes muligheter for å arbeide innen områder med mer hanskebruk i fremtiden.

\section{Diskusjon}

Hanskerelatert håndurtikaria har også blitt kalt lokalisert dermografisme (2 2 ), da sykdommen er symptomatisk dermografisme lokalisert til hendene (3). Symptomatisk dermografisme er den vanligste formen for fysikalsk urtikaria, som er en undergruppe av kronisk, induserbar urtikaria (4).

Prevalensen av dermografisme i den generelle befolkningen er anslått til å være rundt $5 \%$ (4). I likhet med annen symptomatisk dermografisme synes hanskerelatert håndurtikaria å forekomme hyppigere hos kvinner (5). Kronisk urtikaria påvirker livskvaliteten og arbeidslivet til pasientene. Sykdomsbyrden for samfunnet og helsevesenet er stor grunnet høy prevalens, lang varighet og behandlingsresistens (ㅁ$)$.

Sykdommen er forårsaket av trykk som oppstår ved friksjon ved gjentatt på- og avtaking av hansker og/eller av selve trykket på huden fra hanskene $(\underline{2}, \mathbf{7}$.$) .$

Sykdommen er hovedsakelig beskrevet hos helsearbeidere som hyppig bruker engangshansker på jobb. Symptomene kan debutere ved bytte til hansker med trang passform på arbeidsplassen (7.). Nitrilhansker kan gi mer symptomer, da de ofte er mindre fleksible enn latekshansker $(5,7$.$) .$ 
Hanskerelatert håndurtikaria bør mistenkes hos pasienter som får umiddelbar urtikariell hudreaksjon ved bruk av alle typer engangshansker og som har negative allergitester mot lateks og gummitilsetningsstoffer. Diagnosen stilles ved detaljert sykehistorie, positiv test for dermografisme og eksklusjon av allergi $(3,5,7$.7). Symptomene reproduseres ved bruk av trange hansker og bedres ved bruk av mer rommelige hansker $(\underline{2}, 7.7)$.

Behandlingen er bruk av rommelige hansker, forsiktighet ved påføring og avtaking av hansker og profylaktisk bruk av annengenerasjons antihistaminer hvis nødvendig $(5,7$. ).

Sykdommen er sannsynligvis underdiagnostisert og er en viktig differensialdiagnose til kontaktallergi.

Pasienten har gitt samtykke til at artikkelen blir publisert. Artikkelen er fagfellevurdert.

\section{LITTERATUR}

1. Armstrong DKB, Smith HR, Rycroft RJG. Glove-related hand urticaria in the absence of Type I latex allergy. Contact Dermat 1999; 41: 42. [PubMed][CrossRef]

2. Thomson KF, Wilkinson SM. Localized dermographism: a differential diagnosis of latex glove allergy. Contact Dermat 1999; 41:103-4. [PubMed][CrossRef]

3. Golberg O, Johnston GA, Wilkinson M. Symptomatic dermographism mimicking latex allergy. Dermatitis 2014; 25: 101-3. [PubMed][CrossRef]

4. Radonjic-Hoesli S, Hofmeier KS, Micaletto S et al. Urticaria and Angioedema: an Update on Classification and Pathogenesis. Clin Rev Allergy Immunol 2018; 54: 88-101. [PubMed][CrossRef]

5. Hawkey S, Abdul Ghaffar S. Glove-related hand urticaria: an increasing occupational problem among healthcare workers. Br J Dermatol 2016; 174: 1137-40. [PubMed][CrossRef]

6. Gonçalo M, Gimenéz-Arnau A, Al-Ahmad M et al. The global burden of chronic urticaria for the patient and society. Br J Dermatol 2021; 184: 226-36. [PubMed][CrossRef]

7. Sheeran C, Cahill J, Nixon R. Glove-related hand urticaria caused by disposable gloves in healthcare workers. Contact Dermat 2014; 71: 115-6. [PubMed][CrossRef]

Publisert: 11. oktober 2021. Tidsskr Nor Legeforen. DOI: 10.4045/tidsskr.21.0050

Mottatt 19.1.2021, første revisjon innsendt 13.4.2021, godkjent 19.5.2021.

Publisert under åpen tilgang CC BY-ND. Lastet ned fra tidsskriftet.no 26. april 2023. 